\title{
Tumor Microenvironmental Responsive Liposomes Simultaneously Encapsulating Biological and Chemotherapeutic Drugs for Enhancing Antitumor Efficacy of NSCLC [Corrigendum]
}

Kong $\mathrm{L}$, Zhang $\mathrm{S}$, Chu $\mathrm{J}$, et al. Int $\mathrm{J}$ Nanomedicine. 2020;15:6451-6468.

The authors have advised due to an error at the time of figure assembly, Figure 6A on page 6463 is incorrect. The correct Figure 6 is shown below.
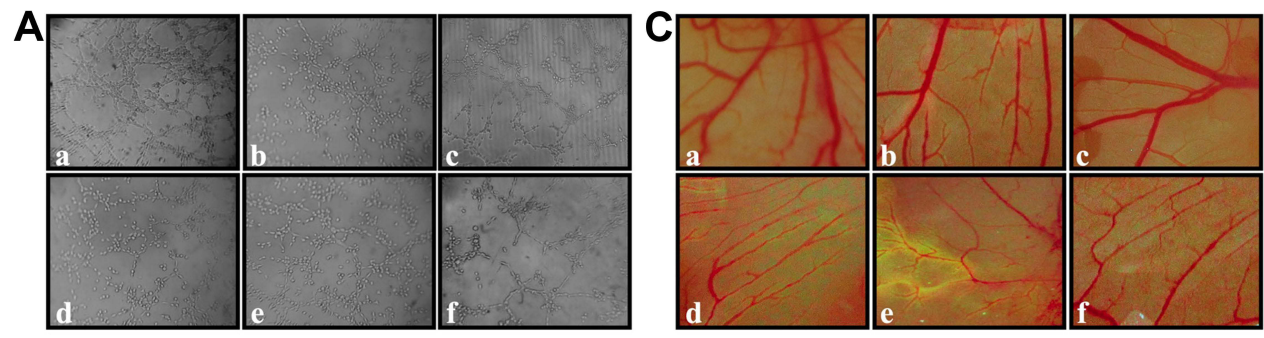

B

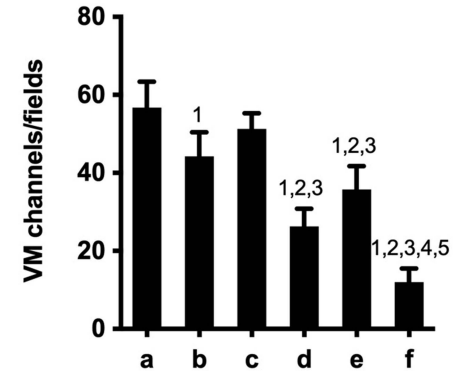

D

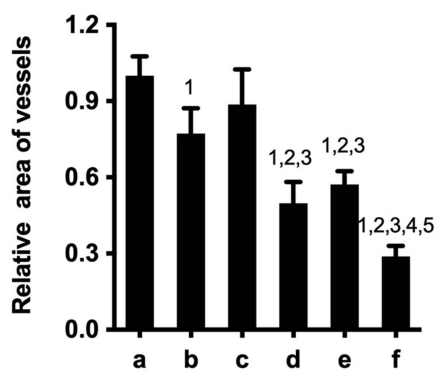

The authors apologize for this error and advise it does not affect the results of the paper.

Figure 6 Inhibitory effects on VM channels formation and angiogenesis after treatment with varying liposomal formulations. (A) Inhibition of VM channels formation in vitro, scale bar $=50 \mu \mathrm{m}$; (B) quantitative analysis of the number of VM channels; (C) inhibition of angiogenesis on CAM after treatment with the varying liposomal formulations, scale bar=5 mm; (D) analysis of relative area vessels after treatment with the varying liposomal formulations. Data are presented as mean $\pm S D$ ( $n=6$ ). a. Blank control; $b$. Dioscin liposomes; c. Vinorelbine liposomes; d. Vinorelbine plus dioscin liposomes; e. CPP (mmp) modified vinorelbine plus dioscin liposomes; f. CPP (mmp) modified vinorelbine plus dioscin liposomes incubated with MMP2 enzymes; I, vs a; 2 , vs b; 3 , vs c; 4 , vs d; 5 , vs e. $P<0.05$.

\section{Publish your work in this journal}

The International Journal of Nanomedicine is an international, peerreviewed journal focusing on the application of nanotechnology in diagnostics, therapeutics, and drug delivery systems throughout the biomedical field. This journal is indexed on PubMed Central, MedLine, CAS, SciSearch ${ }^{\mathbb{R}}$, Current Contents ${ }^{\mathbb{R}} /$ Clinical Medicine,
Journal Citation Reports/Science Edition, EMBase, Scopus and the Elsevier Bibliographic databases. The manuscript management system is completely online and includes a very quick and fair peer-review system, which is all easy to use. Visit http://www.dovepress.com/ testimonials.php to read real quotes from published authors. 